\title{
Combination of L-gossypol and low-concentration doxorubicin induces apoptosis in human synovial sarcoma cells
}

\author{
XILIN BAOLERI ${ }^{1}$, CHAO DONG $^{2}$, YANG ZHOU $^{2}$, ZHAOJUN ZHANG $^{2}$, \\ XUELIANG LU ${ }^{2}$, PENGMING XIE ${ }^{2}$ and YONGQI $\mathrm{LI}^{2}$ \\ ${ }^{1}$ Department of Bone, International Mongolia Hospital of Inner Mongolia, Huhehot, Inner Mongolia 010020; \\ ${ }^{2}$ Department of Bone and Soft Tissue Tumors, Affiliated Cancer Hospital of Xinjiang Medical University, \\ Urumqi, Xinjiang 830011, P.R. China
}

Received March 8, 2014; Accepted November 20, 2014

DOI: $10.3892 / \mathrm{mmr} .2015 .4127$

\begin{abstract}
The current study aimed to investigate the function of L-gossypol and low-concentration doxorubicin (LCD) in the apoptosis of SW982 human synovial sarcoma cells (HSSCs). Wright-Giemsa staining, Hoechst 33258 staining and transmission electron microscopy were used to identify cellular morphological alterations. In addition, an MTT assay was performed to measure the inhibitory rate of the drug, flow cytometry was used to detect alterations in apoptosis and the cell cycle, and western blot analysis was used to detect Bcl-2 and Bax protein expression levels. Furthermore, the activity levels of caspase-3 and -9 were measured in apoptotic cells. Following combination therapy, significant alterations in cellular morphology were observed, including condensation of the nucleus and formation of apoptotic bodies. Cell growth was demonstrated to be inhibited significantly in a dose- and time-dependent manner. Flow cytometry results indicated that L-gossypol administration resulted in $\mathrm{G}_{1}$ phase arrest, whereas doxorubicin led to $S$ phase arrest. Combination therapy resulted in a significant increase in the number of $\mathrm{S}$ phase-arrested cells. Following treatment with the drugs, $\mathrm{Bcl}-2$ protein levels were observed to be reduced whilst Bax levels increased, and significant caspase-3 and -9 activation was observed during combination therapy. Combination therapy with L-gossypol and LCD inhibited cell proliferation and induced apoptosis in SW982 HSSCs at a significantly greater level compared with either treatment alone. It was hypothesized that these effects are mediated via downregulation of the $\mathrm{Bcl}-2$ protein and upregulation of Bax protein.
\end{abstract}

Correspondence to: Professor Xilin Baoleri, Department of Bone, International Mongolia Hospital of Inner Mongolia, 83 Daxue East Street, Huhehot, Inner Mongolia 010020, P.R. China

E-mail: xilinbaoleri@126.com

Key words: L-gossypol, doxorubicin, SW982, apoptosis

\section{Introduction}

Synovial sarcoma (SS) is one of four common soft tissue sarcomas and accounts for 5-10\% of the total incidence of soft tissue sarcomas. Diagnosis and classification of this malignant tumor type is difficult (1); 40\% of cases exhibit metastasis within 2 years (2) and the five-year survival rate of high-level $\mathrm{SS}$ is $\sim 50-60 \%$ (3). Thus, there is a critical demand to establish effective therapeutic strategies for SS.

Doxorubicin is an anthracycline antibiotic widely used in clinical treatment of various types of cancer, including SS. It has been suggested that it functions primarily via insertion into DNA topoisomerase II, in order to cleave the DNA and destroy its structure (4). Doxorubicin is known to affect cells in all phases, but cells in the $\mathrm{S}$ phase are considered to be the most sensitive to doxorubicin (5). Doxorubicin is a recommended drug in the National Comprehensive Cancer Network Guidelines for Soft tissue Sarcoma (6), however it presents various side-effects, including nausea, vomiting, alopecia, high fever and bone marrow suppression. In particular, the cardiotoxic effects of doxorubicin limit its clinical application (7). Thus, the current study presents a novel combination therapy, which may be an improved treatment strategy.

Gossypol is an anticancer drug (8) that is able to significantly inhibit cancer cell proliferation and induce apoptosis in vitro (9-12). L-gossypol is the principal active component of gossypol, and certain cell types are 5-fold more sensitive to L-gossypol than gossypol (13). L-gossypol has various advantages over gossypol, including that it is more widely available, safer and has fewer reported side-effects (14). It has also been demonstrated to inhibit growth and promote apoptosis in squamous cell carcinoma (15). The aim of the present study was to investigate the effects of L-gossypol and low-concentration doxorubicin (LCD) combination therapy on growth inhibition and apoptotic induction in SW982 human SS cells (HSSCs). In the current study, the mechanisms of apoptosis induced by L-gossypol/LCD combination therapy were investigated in the SW982 cell line.

\section{Materials and methods}

Cell culture and experimental groups. SW982 cells were obtained from the American Type Culture Collection 
Table I. Drug and dose combinations by factorial design.

\begin{tabular}{llllll}
\hline Combination & D0 & D1 & D2 & D3 & D4 \\
\hline G0 & G0D0 & G0D1 & G0D2 & G0D3 & G0D4 \\
G1 & G1D0 & G1D1 & G1D2 & G1D3 & G1D4 \\
G2 & G2D0 & G2D1 & G2D2 & G2D3 & G2D4 \\
G3 & G3D0 & G3D1 & G3D2 & G3D3 & G3D4 \\
G4 & G4D0 & G4D1 & G4D2 & G4D3 & G4D4 \\
G5 & G4D0 & G4D1 & G4D2 & G4D3 & G4D4
\end{tabular}

D0-5 and G0-5 represent the concentrations ( $\mu \mathrm{mol} / \mathrm{l})$ of doxorubicin and gossypol, respectively, used in the experiments. D0, 0; D1, 0.01; D2, 0.02; D3, 0.05; D4, 0.1; D5, 0.2; G0, 0; G1, 0.5; G2, 1.0; G3, 1.5; G4, 2.0; G5, 2.5 .

(Manassas, VA, USA) cultured in L-15 medium (Gibco Life Technologies, Grand Island, NY, USA) containing 10\% FBS (Gibco Life Technologies), $100 \mathrm{U} / \mathrm{ml}$ penicillin and $100 \mathrm{U} / \mathrm{ml}$ streptomycin (Shandong Lukang Record Pharmaceutical Co., Ltd., Jining, China), and were incubated at $37^{\circ} \mathrm{C}$ with $5 \% \mathrm{CO}_{2}$. L-gossypol was provided by Professor Tang Hui, University of Shihezi (Shihezi, China). Doxorubicin (Bio Basic, Inc., Amherst, NY, USA).

The experimental groups were divided as follows: i) Control group, cells cultured in the medium described; ii) L-gossypol group, $2.5 \mu \mathrm{mol} / 1 \mathrm{~L}$-gossypol; iii) doxorubicin group, $0.2 \mu \mathrm{mol} / 1$ doxorubicin; iv) combination group, $2.5 \mu \mathrm{mol} / 1 \mathrm{~L}$-gossypol and $0.2 \mu \mathrm{mol} / 1$ doxorubicin. The culture medium was replenished every 3-4 days and the cells were trypsinized (Gibco Life Technologies) and replated at $85 \%$ confluence.

MTT assay. MTT [3-(4,5-dimethylthiazol-2-yl)-2,5-diphenyl tetrazolium bromide; MP Biomedicals, LLC, Santa Ana, CA, USA] assays were performed in accordance with the manufacturer's instructions. The effect of five different concentrations of doxorubicin $(0.01,0.02,0.05,0.1$ and $0.2 \mu \mathrm{mol} / \mathrm{l})$ and L-gossypol $(0.0,0.5,1.0,1.5,2.0$ and $2.5 \mu \mathrm{mol} / \mathrm{l})$ were investigated. The drug combinations were designed in accordance with the factorial design and are listed in Table I.

The cells were seeded during the logarithmic growth phase onto 96 -well plates at a density of $5 \times 10^{4}$ cells $/ \mathrm{ml}(100 \mu \mathrm{l} /$ well $)$ with five parallel wells. The experimental drugs were added, resulting in a final volume of $200 \mu \mathrm{l} /$ well. Subsequently, $20 \mu \mathrm{l}$ MTT/well was incubated for $4 \mathrm{~h}$ at $37^{\circ} \mathrm{C}$, then the supernatant was removed, $150 \mu 1$ dimethyl sulfoxide was added, and the plates were incubated for a further $10 \mathrm{~min}$. The absorbance was then measured using an xMark Microplate Absorbance Spectrophotometer (Bio-Rad Laboratories, Inc., Hercules, CA, USA) at a wavelength of $490 \mathrm{~nm}$. The absorbance values at 24, 48,72 and $96 \mathrm{~h}$ were measured in order to calculate the $\mathrm{IC}_{50}$ (the concentration resulting in 50\% inhibition) and inhibitory rates using the following formula: Inhibitory rate $=(1-$ absorbance of the experimental group/absorbance of the control group) $\mathrm{x} 100 \%$

Cellular morphology. Wright-Giemsa staining (Nanjing Jiangcheng Bioengineering Institute, Nanjing, China) was conducted according to the manufacturer's instructions on
$1 \times 10^{5}$ cells/ml seeded in 6-well plates, cultured for $24 \mathrm{~h}$ with the experimental drug. Cellular morphology was observed under an IX71 inverted optical microscope (Olympus Corporation, Tokyo, Japan). Hoechst 33258 (Sigma-Aldrich, St. Louis, MO, USA) staining was conducted on $1 \times 10^{6}$ cells per experimental group under the microscope. Ultra-thin sections $(70-90 \mathrm{~nm})$ were cut from samples of the control and $24 \mathrm{~h}$ treatment groups using a Reichert Ultracut-E ultramicrotome (Reichert-Jung, Vienna, Austria). Cells from the prepared sections were visualized using transmission electron microscopy (TEM) on a JEOL 1230 Transmission Electron Microscope (JEOL, Ltd., Tokyo, Japan).

Flow cytometry. A total of $1 \times 10^{6}$ cells from each of the experimental and drug-treated ( 24 and $48 \mathrm{~h}$ ) groups were collected and resuspended in $1 \mathrm{ml} 10 \mathrm{X}$ annexin $\mathrm{V}$ binding buffer from a FITC Annexin V Apoptosis Detection Kit I (BD Biosciences, San Jose, CA, USA). A total of $100 \mu \mathrm{l}$ of the solution was transferred into a cell culture tube; $5 \mu \mathrm{l}$ fluorescein isothiocyanate (FITC)-annexin V and $5 \mu \mathrm{l}$ propidium iodide (PI) from the kit were added. Simultaneously, FITC and PI were added to the blank well. Subsequent to mixing, the solution was cultured at room temperature in the dark for $15 \mathrm{~min}, 400 \mu \mathrm{l}$ combined buffer was added into the cell culture tube, and flow cytometry was conducted using an Epics Altra Flow Cytometer (Beckman Coulter, Inc., Miami, FL, USA).

Detection of alterations in the cell cycle. A total of $1 \times 10^{6}$ cells from each of the experimental and drug-treated (24 and $48 \mathrm{~h})$ groups were collected for flow cytometry. The cells were centrifuged at $300 \mathrm{x}$ g for $5 \mathrm{~min}$, washed twice with phosphate-buffered saline (PBS), fixed with $1 \mathrm{ml}$ ice cold $70 \%$ ethanol and mixed, then maintained at $4^{\circ} \mathrm{C}$ for $24 \mathrm{~h}$. Prior to testing, the mixture was centrifuged at $1,500 \mathrm{rpm}$ for $5 \mathrm{~min}$ and washed twice with PBS prior to the addition of $400 \mu \mathrm{l}$ RNA enzyme (30 $\mu \mathrm{g} / \mathrm{ml}$; Sigma-Aldrich). The cells were then incubated at $37^{\circ} \mathrm{C}$ for $30 \mathrm{~min}$, mixed with $100 \mu \mathrm{PI}(200 \mu \mathrm{g} / \mathrm{ml})$ and incubated in the dark at $4^{\circ} \mathrm{C}$ for $30 \mathrm{~min}$ prior to flow cytometry. The cell distribution percentages for the $\mathrm{G}_{1}, \mathrm{~S}$ and $\mathrm{G}_{2}$ phases were then calculated using EXPO 32 MultiComp software, version 1.2 (Beckman Coulter, Inc.).

Western blotting. A total of $100 \mu \mathrm{g}$ protein was collected from the experimental and $24 \mathrm{~h}$ drug-treated groups. Protein samples underwent polyacrylamide gel electrophoresis with 
Table II. Analysis of variance.

\begin{tabular}{|c|c|c|c|c|c|c|c|}
\hline & Doxorubicin & L-gossypol & $\mathrm{T}$ & $\mathrm{D}, \mathrm{T}$ & $\mathrm{G}, \mathrm{T}$ & G,D & $\mathrm{D}, \mathrm{G}, \mathrm{T}$ \\
\hline F-ratio & 1175.682 & 750.205 & 4223.069 & 39.296 & 61.691 & 2.459 & 1.565 \\
\hline P-value & $<0.001$ & $<0.001$ & $<0.001$ & $<0.001$ & $<0.001$ & $<0.001$ & $=0.005$ \\
\hline
\end{tabular}

T, combined effect; D, doxorubicin; G, L-gossypol.
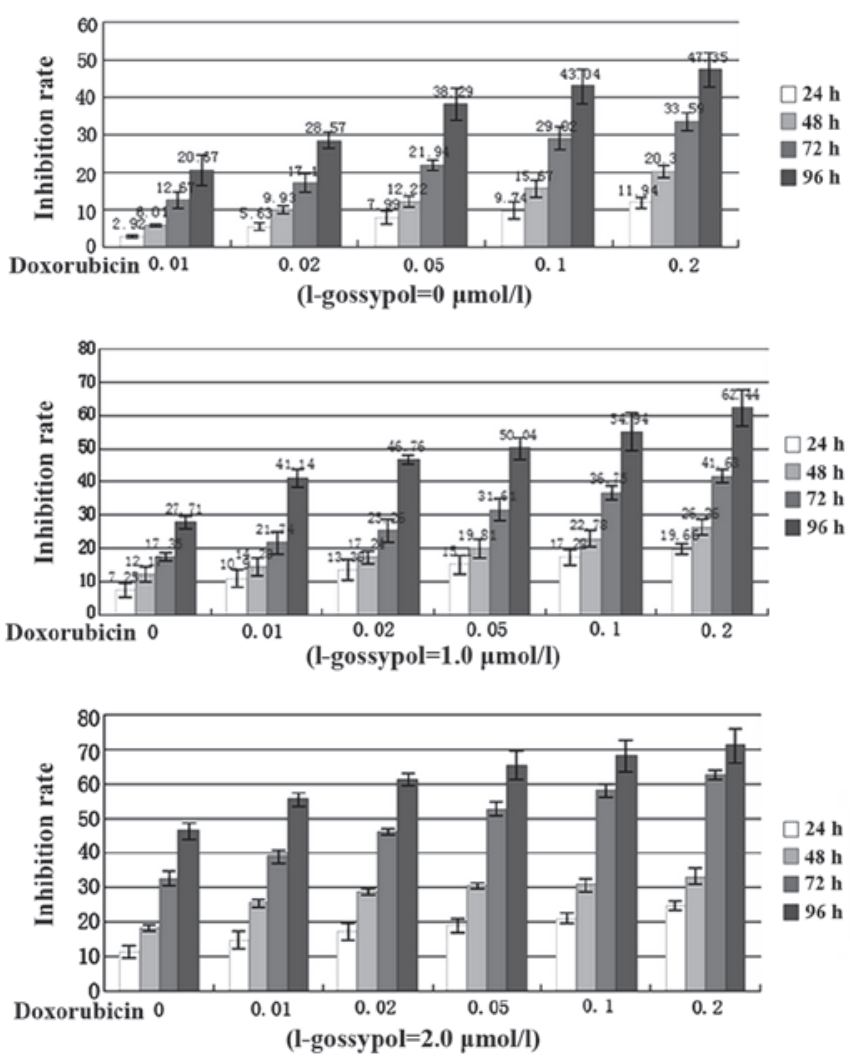
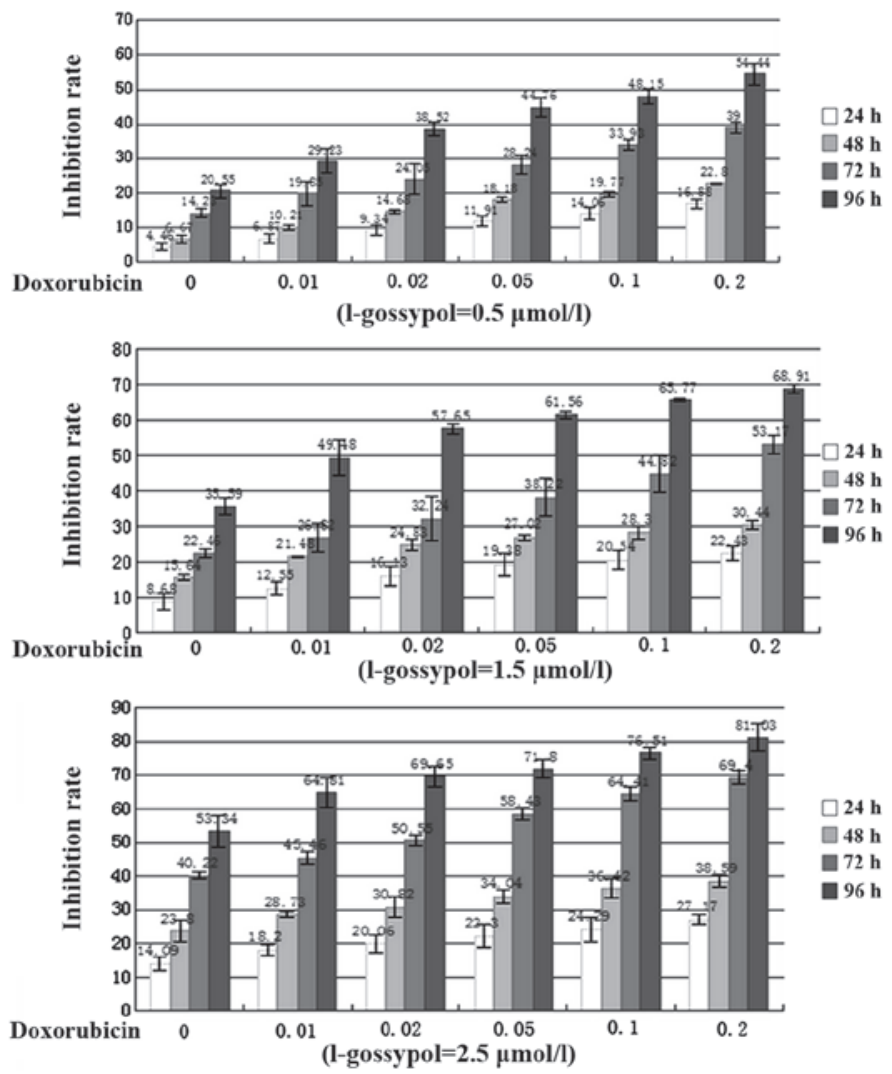

Figure 1. Impacts of different concentrations of doxorubicin and L-gossypol on the cell inhibition rate following $96 \mathrm{~h}$-combination therapy.

$8 \%$ gel at $80 \mathrm{~V}$ (Wuhan Boster Biological Technology, Ltd., Wuhan, China) and were subsequently transferred onto polyvinylidene difluoride membranes. The samples were then blocked with nonfat milk and incubated overnight with polyclonal rabbit anti-human Bcl-2 (sc-782) or Bax (sc-493) primary antibodies (Santa Cruz Biotechnology, Inc., Dallas, TX, USA) overnight at $4^{\circ} \mathrm{C}$. Blots were incubated with the horseradish peroxidase-conjugated secondary antibody (1:5,000; anti-IgG; Santa Cruz Biotechnology, Inc.). The secondary antibody was added and incubated at $37^{\circ} \mathrm{C}$ for $2 \mathrm{~h}$ and visualized using staining with 3,3'-diaminobenzidine (Beijing Solarbio Science \& Technology Co., Ltd., Beijing, China). Quantity One 1-D analysis software, version 4.6.2 (Bio-Rad Laboratories, Inc.) was used for analysis of the grayscale values. The relative expression level of the target protein was calculated as follows: Target protein band gray value/internal reference ( $\beta$-actin) gray value.

Caspase-3 and -9 activity analysis. A total of $1 \times 10^{6}$ cells were collected from each of the experimental and the drug-treated groups at $0,6,12,18$ and $24 \mathrm{~h}$. These were analyzed using the Caspase-3 and Caspase-9 Colorimetric Assay kits (R\&D Systems, Inc., Minneapolis, MN, USA), at a wavelength of $405 \mathrm{~nm}$. The activity levels of caspase-3 and -9 in the control group were set as 1 , while the optical density (OD) value/the control group OD was used to represent the activity of caspase- 3 and -9 in the other groups. The formula used was as follows: Caspase- 9 and -3 activity $=\left(\mathrm{OD}^{405}\right.$ of sample - OD ${ }^{405}$ of blank $) /\left(\mathrm{OD}^{405}\right.$ of control - OD ${ }^{405}$ of blank).

Statistical analysis. The current study used factorial design and the experiment was repeated three times with the results presented as the mean \pm standard deviation. All data obtained were analyzed using SPSS software, version 18.0 (SPSS, Inc., Chicago, IL, USA). The data met the criteria for independence, normality and homogeneity of variance, therefore a t-test was selected for analysis. In addition, the $\chi^{2}$ test was used when appropriate, with the test level set as $\alpha=0.05$. $\mathrm{P}<0.05$ was considered to indicate a statistically significant difference. 

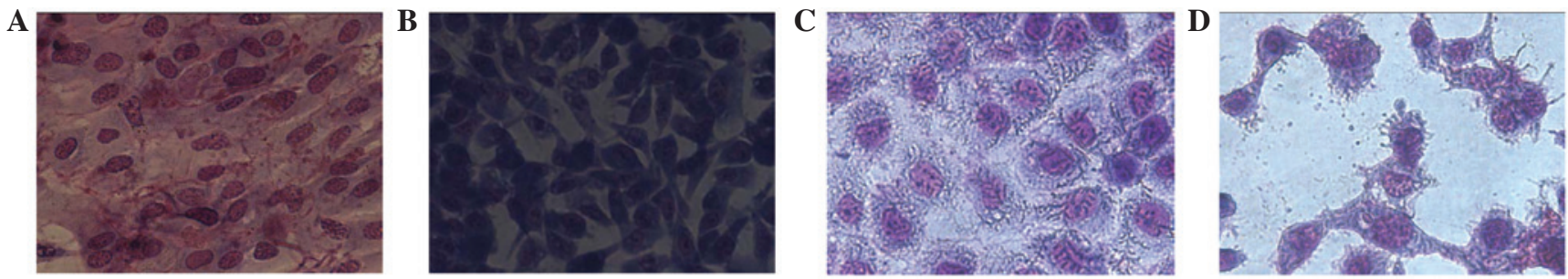

Figure 2. Wright-Giemsa staining illustrating apoptosis of SW982 cells following the action of doxorubicin and L-gossypol (magnification, x200). (A) Control group, (B) doxorubicin group, (C) L-gossypol group and (D) combination group.
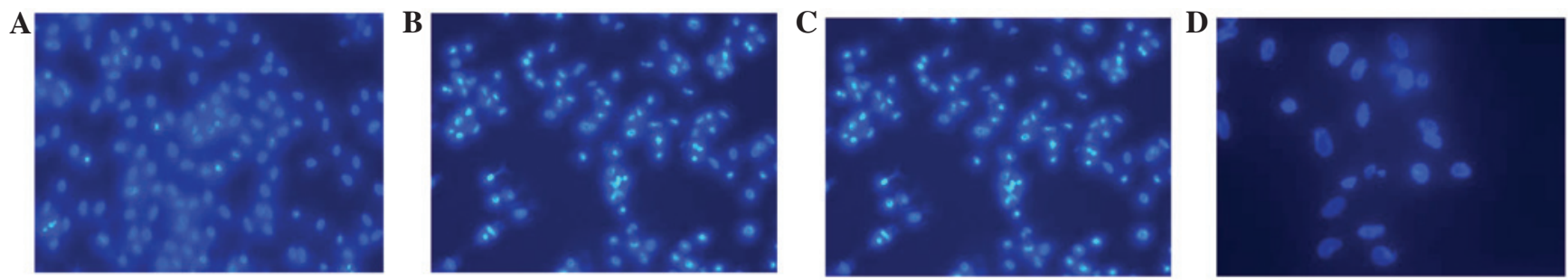

Figure 3. Hoechst 33258 staining illustrating apoptosis of SW982 cells following the action of doxorubicin and L-gossypol (magnification, x200). (A) Control group, (B) doxorubicin group, (C) L-gossypol group and (D) combination group.
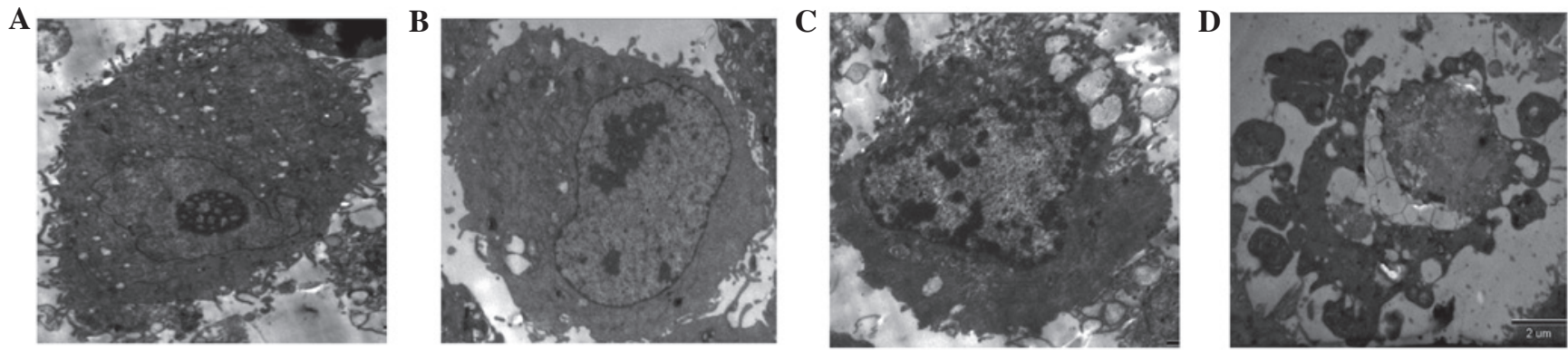

Figure 4. Stages of apoptosis visualized using transmission electron microscopy. (A) Control group, (B) doxorubicin group, (C) L-gossypol group and (D) combination group. In the control group, the structure of cells was normal. In the doxorubicin group and L-gossypol group, cells in the early apoptotic stage and middle apoptotic stage could be observed. In the combination goup, numerous cells were in the late apoptotic stage.

\section{Results}

Cell proliferation. L-gossypol and LCD exhibited different degrees of time-dependent inhibition on the proliferation of SW982 cells (Fig. 1). The $\mathrm{IC}_{50} \mathrm{~s}$ of L-gossypol were 16.2, 4.7, 3.9 and $2.5 \mu \mathrm{mol} / 1$ at $24,48,72$ and $96 \mathrm{~h}$, respectively, whereas those of LCD were 5.12, 1.06, 0.32 and $0.20 \mu \mathrm{mol} / \mathrm{l}$ at 24, 48, 72 and $96 \mathrm{~h}$, respectively. In addition, the combined inhibitory effect of L-gossypol and LCD exhibited a clear increase in a concentration- and time-dependent manner $(\mathrm{P}<0.001)$, indicating a strong synergy between the two drugs (Fig. 1, Table II).

Inverted phase contrast microscopy. Wright-Giemsa staining was conducted on SW982 HSSCs cocultured in $2.5 \mu \mathrm{mol} / 1 \mathrm{~L}$-gossypol and/or $0.2 \mu \mathrm{mol} / 1$ doxorubicin for $48 \mathrm{~h}$, which revealed distinct morphological differences between the groups (Fig. 2). Control cells were tightly packed, large and predominantly appeared as clostridial forms with few cells exhibiting the polygonal form. The nuclei were large and centrally located, and a small number of cells deviated from the standard form. The majority of cells in the control group were observed to have two nuclei and the cytoplasm was abundant.
However, in the experimental groups, the number and size of the cells was significantly reduced. In addition, a larger number of cells appeared to be irregular in shape and a small number were circular. The nuclei were observed to shrink in certain cells, while in others the nuclei fragmented, the fragments of which were observed moving towards the outer part of cells, forming film-coated apoptotic bodies (Fig. 2).

Fluorescence microscopy. Control HSSCs were observed to be condensed, granular and exhibit clear fluorescence in either the nuclei or the cytoplasm following $48 \mathrm{~h}$ of treatment (Fig. 3). In addition, apoptosis was clearly evident. The cells shrank, the chromatin became condensed and marginated and clear fragments were observed inside the cytoplasm. The cell membrane was observed to form bubble-like protrusions and apoptotic bodies were formed.

TEM. The results from the TEM demonstrated that the control HSSCs were oval, with a large number of microvilli on the cell surface. The nuclei were clearly visible, the distribution of intranuclear chromatin was uneven and intracytoplasmic mitochondria were common (Fig. 4). Following drug coculture, 
Table III. Impact analysis of cell apoptosis.

\begin{tabular}{|c|c|c|c|c|c|}
\hline \multirow[b]{2}{*}{ Group } & \multirow[b]{2}{*}{ Apoptotic rate } & \multicolumn{2}{|c|}{ ANOVA of factorial design } & \multicolumn{2}{|c|}{ ANOVA of single factor } \\
\hline & & F-ratio & P-value & F-ratio & P-value \\
\hline Control & $4.30 \pm 0.26$ & & & 107.562 & $<0.001$ \\
\hline Doxorubicin & $23.20 \pm 2.45^{\mathrm{ac}}$ & 205.342 & $<0.001$ & & \\
\hline L-gossypol & $18.40 \pm 2.20^{\mathrm{ab}}$ & 117.082 & $<0.001$ & & \\
\hline Combination & $38.70 \pm 3.40^{\mathrm{abc}}$ & 0.262 & 0.623 & & \\
\hline
\end{tabular}

${ }^{\text {a }} \mathrm{P}<0.001$ vs. the control group; ${ }^{\mathrm{b}} \mathrm{P}<0.05$ vs. the doxorubicin group; ${ }^{\mathrm{C}} \mathrm{P}<0.01 \mathrm{vs}$. the L-gossypol group. ANOVA, analysis of variance.

Table IV. Alterations in the cell cycle following drug treatment of SW982 cells for $24 \mathrm{~h}$.

\begin{tabular}{|c|c|c|c|c|c|c|c|}
\hline \multirow[b]{2}{*}{ Group } & \multirow[b]{2}{*}{$\mathrm{G}_{1}$} & \multicolumn{2}{|c|}{ ANOVA of factorial design } & \multirow[b]{2}{*}{$\mathrm{G}_{2}$} & \multirow[b]{2}{*}{$\mathrm{S}$} & \multicolumn{2}{|c|}{ ANOVA of factorial design } \\
\hline & & F-ratio & P-value & & & F-ratio & P-value \\
\hline Control & $78.56 \pm 2.51$ & & & $7.18 \pm 0.93$ & $13.31 \pm 2.45$ & & \\
\hline Doxorubicin & $83.75 \pm 1.48^{\mathrm{a}}$ & 5.32 & 0.05 & $9.16 \pm 1.42$ & $5.53 \pm 1.45^{\mathrm{a}}$ & 13.77 & 0.01 \\
\hline L-gossypol & $86.32 \pm 3.15^{\mathrm{ab}}$ & 18.93 & $<0.001$ & $8.52 \pm 2.42$ & $3.90 \pm 1.95^{\mathrm{a}}$ & 27.39 & $<0.001$ \\
\hline Combination & $86.96 \pm 0.84^{\mathrm{a}}$ & 3.26 & 0.11 & $8.32 \pm 2.05$ & $3.80 \pm 1.56^{\mathrm{a}}$ & 13.03 & 0.01 \\
\hline F-ratio & 9.169 & & & 0.670 & 18.063 & & \\
\hline P-value & 0.006 & & & 0.594 & 0.001 & & \\
\hline
\end{tabular}

${ }^{\mathrm{a}} \mathrm{P}<0.005$ vs. the control group; ${ }^{\mathrm{b}} \mathrm{P}<0.05$ vs. the doxorubicin group; $\mathrm{P}<0.01$ vs. the L-gossypol group. ANOVA, analysis of variance.

Table V. Alterations in the cell cycle following drug treatment of SW982 cells for $48 \mathrm{~h}$.

\begin{tabular}{|c|c|c|c|c|c|c|c|}
\hline \multirow[b]{2}{*}{ Group } & \multirow[b]{2}{*}{$\mathrm{G}_{1}$} & \multicolumn{2}{|c|}{ ANOVA of factorial design } & \multirow[b]{2}{*}{$\mathrm{G}_{2}$} & \multirow[b]{2}{*}{$\mathrm{S}$} & \multicolumn{2}{|c|}{ ANOVA of factorial design } \\
\hline & & F-ratio & P-value & & & F-ratio & P-value \\
\hline Control & $80.95 \pm 1.61$ & & & $8.41 \pm 0.83$ & $9.48 \pm 0.65$ & & \\
\hline Doxorubicin & $76.71 \pm 1.26^{\mathrm{a}}$ & 253.066 & $<0.001$ & $7.18 \pm 0.93$ & $15.03 \pm 1.29^{\mathrm{a}}$ & 705.678 & $<0.001$ \\
\hline L-gossypol & $88.31 \pm 1.26^{\mathrm{ab}}$ & 5.421 & 0.048 & $8.17 \pm 1.82$ & $2.79 \pm 0.32^{\mathrm{ab}}$ & 17.443 & 0.003 \\
\hline Combination & $65.38 \pm 1.73^{\mathrm{abc}}$ & 119.75 & $<0.001$ & $7.13 \pm 0.74$ & $26.29 \pm 1.16^{\mathrm{abc}}$ & 269.791 & $<0.001$ \\
\hline F-ratio & 126.079 & & & 0.978 & 330.97 & & \\
\hline P-value & $<0.001$ & & & 0.450 & $<0.001$ & & \\
\hline
\end{tabular}

${ }^{\mathrm{a}} \mathrm{P}<0.005$ vs. the control group; ${ }^{\mathrm{b}}<0.05$ vs. the doxorubicin group; ${ }^{\mathrm{C}} \mathrm{P}<0.01$ vs. the L-gossypol group. ANOVA, analysis of variance.

the cells appeared to morphologically transition to exhibit apoptotic characteristics. These predominantly manifested as disappearance and condensation of the microvilli on the apoptotic cell surface, and the appearance of marginated intranuclear chromatin. Additionally, in the early cellular stages, HSSCs were crescent-shaped, whilst during the late stage the cells swelled and ruptured, the nuclei shrank and fragmented, a large number of vacuoles appeared in the cytoplasm and apoptotic bodies appeared (Fig. 4).

Analysis of apoptosis. Following coculture for $48 \mathrm{~h}$, the early apoptotic rates of L-gossypol and doxorubicin in the experimental groups were $18.40 \pm 2.20$ and $23.20 \pm 2.45 \%$, respectively, which were significantly higher than the control group $(4.30 \pm 0.26 \%$; $\mathrm{P}<0.001)$ (Table III, Fig. 5). The early apoptotic rate of L-gossypol/doxorubicin combination therapy was $(38.70 \pm 3.40 \%)$. No significant interaction between the two drugs was observed $(\mathrm{P}=0.623)$, however, a single-factor analysis of variance revealed that the apoptotic rate in the combination group was significantly increased compared with the other groups $(\mathrm{P}<0.001)$.

Analysis of cell cycle. The proportion of cells in the $\mathrm{G}_{1}$ phase in the experimental groups increased significantly following 
Table VI. Alterations in Bcl-2 and Bax protein expression levels following drug treatment of SW982 cells for $24 \mathrm{~h}$.

\begin{tabular}{|c|c|c|c|c|c|c|}
\hline \multirow[b]{2}{*}{ Group } & \multirow[b]{2}{*}{ Bcl-2/ß-actin (\%) } & \multicolumn{2}{|c|}{ ANOVA of factorial design } & \multirow[b]{2}{*}{$\operatorname{Bax} / \beta$-actin $(\%)$} & \multicolumn{2}{|c|}{ ANOVA of factorial design } \\
\hline & & F-ratio & P-value & & F-ratio & P-value \\
\hline Control & $32.66 \pm 1.58$ & & & $4.36 \pm 0.60$ & & \\
\hline Doxorubicin & $19.73 \pm 2.01^{\mathrm{a}}$ & 248.663 & $<0.001$ & $12.36 \pm 1.80^{\mathrm{a}}$ & 90.289 & $<0.001$ \\
\hline L-gossypol & $18.30 \pm 1.32^{\mathrm{a}}$ & 199.791 & $<0.001$ & $18.08 \pm 1.46^{\mathrm{ab}}$ & 276.769 & $<0.001$ \\
\hline Combination & $6.43 \pm 0.97^{\mathrm{abc}}$ & 0.365 & 0.562 & $25.31 \pm 1.41^{\mathrm{abc}}$ & 0.2317 & 0.644 \\
\hline F-ratio & 149.607 & & & 122.43 & & \\
\hline P-value & $<0.001$ & & & $<0.001$ & & \\
\hline
\end{tabular}

${ }^{a} \mathrm{P}<0.005$ vs. the control group; ${ }^{\mathrm{b}} \mathrm{P}<0.001$ vs. the doxorubicin group; ${ }^{\mathrm{c}} \mathrm{P}<0.001$ vs. the L-gossypol group. ANOVA, analysis of variance.

A

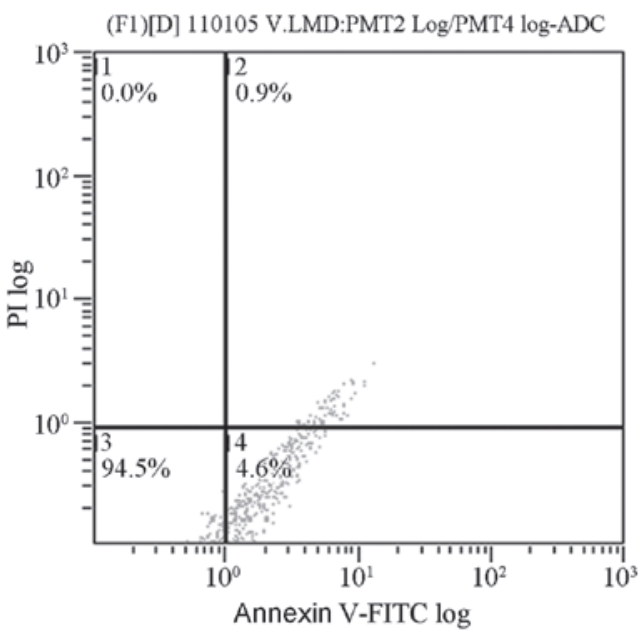

C

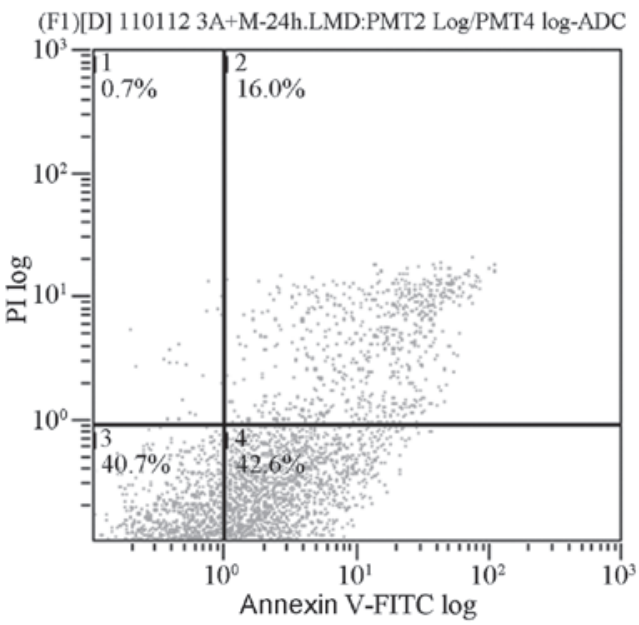

B

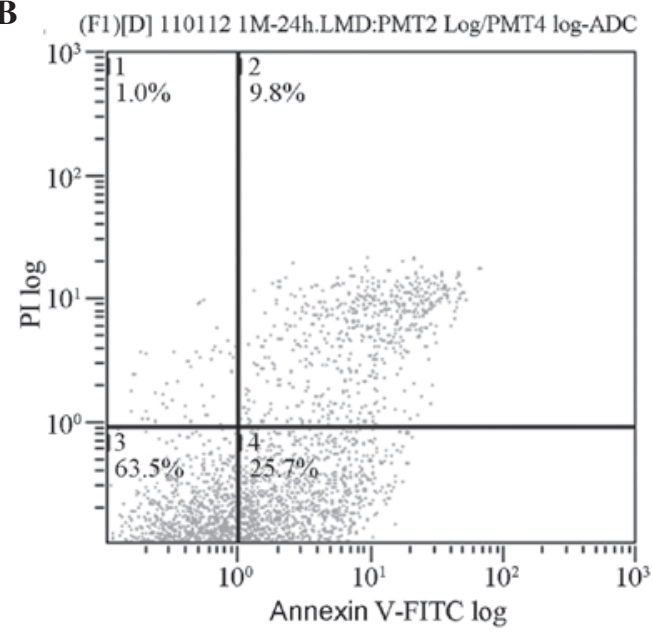

D

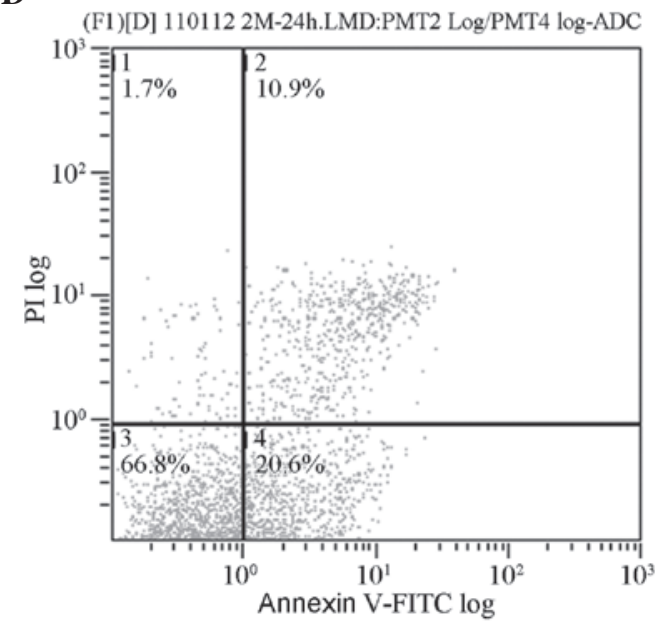

Figure 5. Apoptosis in SW982 cells. (A) Control group, (B) doxorubicin group, (C) combination group and (D) L-gossypol group. Quadrant 4 indicates cells undergoing apoptosis. PI, propidium iodide; FITC, fluorescein isothiocyanate.

24-h drug treatment $(\mathrm{P}=0.05$ and $\mathrm{P}<0.001$ in the doxorubicin and L-gossypol groups, respectively; Table IV). As presented in Table $\mathrm{V}$, following 48-h coculture, the proportion of L-gossypol group cells in the $\mathrm{G}_{1}$ phase increased to $88.31 \pm 1.26 \%$, compared with $80.95 \pm 1.61 \%$ in the control group $(\mathrm{P}=0.048)$. The numbers of cells in the $\mathrm{S}$ phase in the doxorubicin group $(15.03 \pm 1.29 \%)$ and the combination group $(26.29 \pm 1.16 \%)$ were also significantly different compared with the control group $(9.48 \pm 0.65 \% ; \mathrm{P}<0.001)$ and a significant interaction was observed $(\mathrm{P}<0.001)$. These results indicate that L-gossypol predominantly arrests the cells in the $G_{1}$ phase, while doxorubicin and the combination therapy predominantly arrest cells in the S phase (Table IV and V, Fig. 6).

Bcl-2 and Bax protein expression levels. Bcl-2 protein levels following L-gossypol and doxorubicin coculture $(18.30 \pm 1.32 \%$ 
A

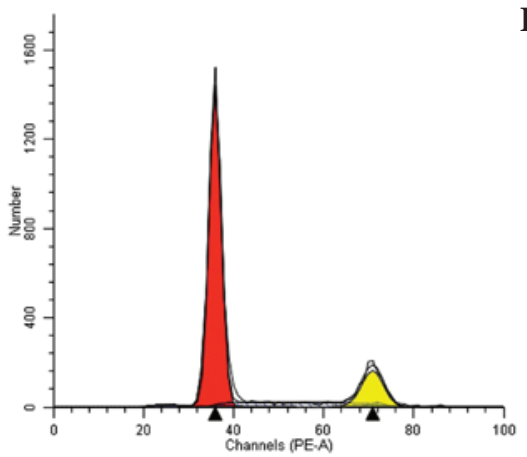

C

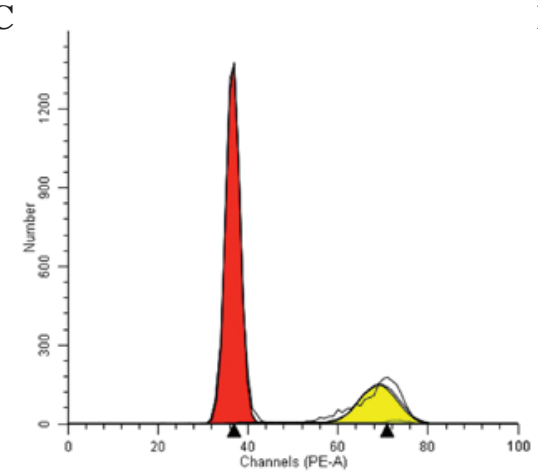

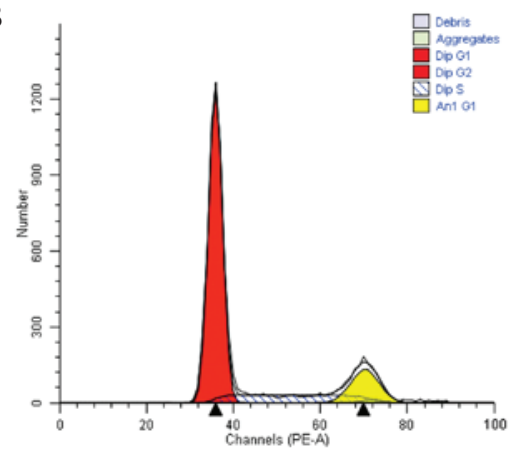

$\mathbf{D}$

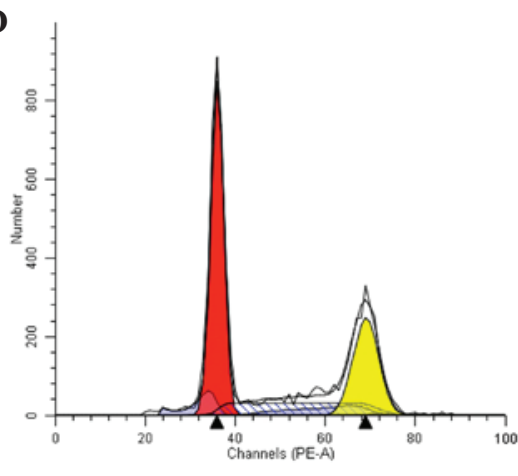

Figure 6. Cell cycles of SW982 cells, analyzed by EXPO 32 MultiComp software. (A) Control group, (B) doxorubicin group, (C) L-gossypol group, (D) combination group.

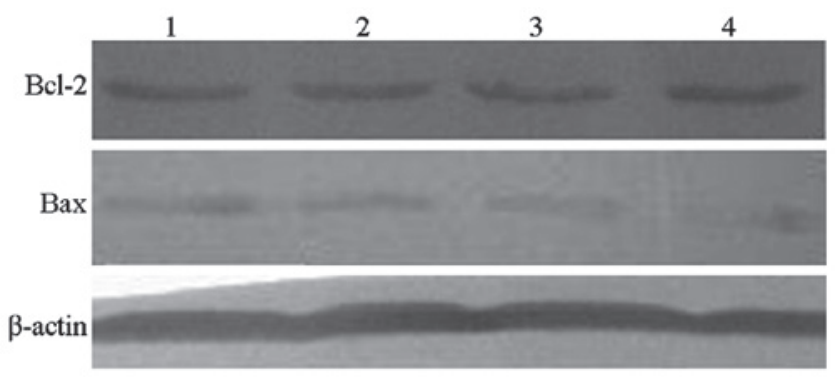

Figure 7. Expression levels of Bcl-2, Bax and $\beta$-actin proteins in SW982 cells following 24 -h action of doxorubicin. 1, control group; 2 , doxorubicin group; 3 , L-gossypol group; 4, combination group.
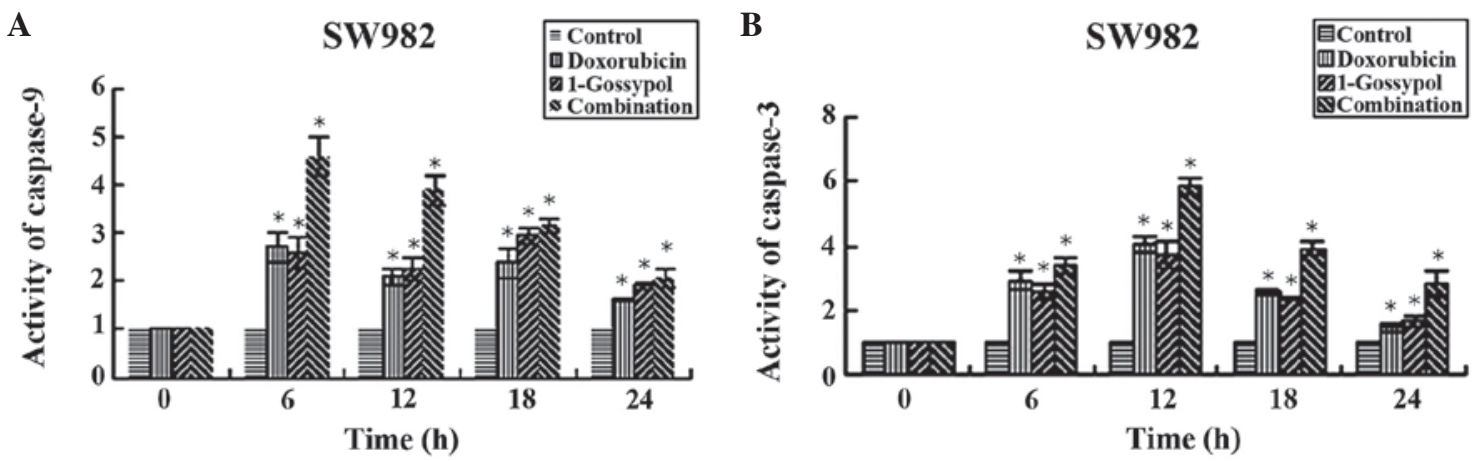

Figure 8. Alterations in levels of (A) caspase-9 and (B) caspase-3 activity at different time points in SW982 cells. "P $<0.05$, compared with the control group.

and $19.73 \pm 2.01 \%$, respectively) were significantly reduced compared with the control group $(32.66 \pm 1.58 \% ; \mathrm{P}<0.001)$ (Table VI and Fig. 7). In addition, during combination therapy, the levels of Bcl-2 were further reduced $(6.43 \pm 0.97 \%)$, while the interaction of the two drugs was not significant. Furthermore, L-gossypol and doxorubicin produced significant increases in Bax protein levels $(18.08 \pm 1.46 \%$ and $12.36 \pm 1.80 \%)$ when compared with the control group $(4.36 \pm 0.60 \%$; $\mathrm{P}<0.001)$. 
Following combination therapy, Bax levels were further increased $(25.31 \pm 1.41 \%)$, however, no significant interaction between the two drugs was observed $(\mathrm{P}=0.644)$.

Caspase-3 and -9 activity. Significant activation of caspase-9 and -3 in SW982 cells was observed in every treatment group at at least one time point, compared with time point $0 \mathrm{~h}$ $(\mathrm{P}<0.05)$. Caspase-9 activity reached its maximum value at $6 \mathrm{~h}$ subsequent to drug administration. Following $12 \mathrm{~h}$, caspase-9 activity began to decline towards the control level. By contrast, no caspase- 3 activity was observed prior to $12 \mathrm{~h}$, and began to reduce at $18 \mathrm{~h}$. The single-factor analysis of variance indicated that the combination group led to a significantly greater increase in caspase activity compared with the L-gossypol group, the doxorubicin group and the control group $(\mathrm{P}<0.05$, Fig. 8). The data also demonstrate that the concentration required to achieve the same inhibitory effect was lower in the combination therapy group (data not shown).

\section{Discussion}

Apoptosis is controlled by various genes and is a process of programmed death that results in alterations in cellular morphology. These alterations include chromatin condensation and peripheralization, cytoplasm reduction and densification, nuclear fragmentation, interruption of surrounding cell contacts and fusion of endoplasmic reticulum and the cell membrane (16). The result of these morphological alterations is the formation of apoptotic bodies from cell fragmentation. The mitochondrial pathway is vital in apoptosis, and a variety of pro-apoptotic factors act on the mitochondria, leading to the opening of the mitochondrial permeability transition pore. Damage to the outer membrane in turn results in an increased permeability of the mitochondrial membrane, thus resulting in a release of apoptosis-associated molecules, which in turn activate apoptotic factors such as caspase- 9 and its downstream factor, caspase-3 (17). This ultimately results in apoptosis. The results of the current study suggest that L-gossypol and/or LCD-induced apoptosis is results from the activation of caspase-9, in addition to downstream caspase- 3 activation.

The results of the current study also demonstrated that L-gossypol and LCD therapy resulted in a clear reduction in $\mathrm{Bcl}-2$ and an increase in Bax protein content. In addition, when these two drugs were used in combination therapy, the alterations in Bcl-2 and Bax protein expression levels were observed to be more pronounced. The members of the Bcl-2 family are important in apoptosis and are widely distributed in the outer mitochondrial membrane, nuclear membrane and endoplasmic reticulum. They possess the ability to either inhibit (via $\mathrm{Bcl}-2$ ), or activate (via Bax) the process of apoptosis. In addition, $\mathrm{Bcl}-2$ has been reported to inhibit the activation of Bax protein (18), isolate or inactivate Bax protein $(19,20)$, form a heterodimer with Bax and inhibit the formation of the Bax/Bax homodimer (21). When the Bax/Bcl-2 heterodimer is formed, Bax loses its ability to alter the permeability of the mitochondrial membrane, and thus cannot induce cellular apoptosis (22-24). Bcl-2 and Bax are part of a dynamic system in which the ratio of $\mathrm{Bcl}-2 / \mathrm{Bax}$ determines whether apoptosis occurs or not $(25,26)$, and this is mediated via caspase-3 $(27,28)$. Therefore, it was hypothesized that L-gossypol and LCD therapies act by altering the ratio of $\mathrm{Bcl}-2$ and Bax protein via a mitochondria-dependent mechanism, which results in the activation of caspase-9. This theory is supported by the observation that combination therapy had a synergistic effect, indicating that these drugs act through the mitochondrial pathway, thus the apoptotic effects are more pronounced when the two drugs are combined.

Cell cycle analysis suggested that L-gossypol blocks cells in the $G_{1}$ phase, while LCD blocks those in the $S$ phase; and the combination of the two drugs significantly increased the number of cells in the $S$ phase. The regulation of the cell cycle is a complex process, but a previous study indicated the $\mathrm{G}_{1} / \mathrm{S}$ checkpoint to be an important point during the cell cycle, at which numerous factors can affect the cycle (29). It has been observed that $10 \mu \mathrm{mol} / \mathrm{l}$ gossypol arrested MCF-7 cells at the $\mathrm{G}_{1} / \mathrm{S}$ checkpoint and inhibited DNA synthesis (30). In addition, gossypol has been identified to reduce the activity of DNA polymerase $\alpha$ and $\beta$, inhibit DNA synthesis and block the cell cycle in the $\mathrm{S}$ phase, thus indicating gossypol as a specific inhibitor of DNA synthesis (31). Certain studies have reported that gossypol does not appear to alter the cell cycle $(32,33)$, however, these discrepancies are speculated to be due to the impact of gossypol on the cell cycle being cell type-specific, or due to differences among gossypol and its derivatives.

In summary, the current study demonstrated for the first time that L-gossypol and LCD produce significant effects on the inhibition of proliferation and the activation of apoptosis in SW982 HSSCs, and that the combination of the two drugs significantly potentiates these effects. It is hypothesized that the mechanism of action of the two drugs is via downregulation of $\mathrm{Bcl}-2$ protein and upregulation of Bax protein levels, in addition to the impacts of these drugs on the cell cycle of the HSSCs. The results of the current study support the use of L-gossypol in combination with other chemotherapeutic drugs in clinical study. In addition, they provide a preliminary theoretical foundation for the clinical use of LCD, which is hypothesized to reduce the dose required and the resultant side-effects. Further investigation is required to fully elucidate the cellular and molecular mechanisms of L-gossypol therapy and the clinical significance of this.

\section{References}

1. van de Rijn M and Fletcher JA: Genetics of soft tissue tumors. Annu Rev Pathol 1: 435-466, 2006.

2. Maki RG: Gemcitabine and docetaxel in metastatic sarcoma: past, present, and future. Oncologist 12: 999-1006, 2007.

3. Tschoep K, Kohlmann A, Schlemmer M, Haferlach T and Issels RD: Gene expression profiling in sarcomas. Crit Rev Oncol Hematol 63: 111-124, 2007.

4. Werner M, Atil B, Sieczkowski E, Chiba P and Hohenegger M: Simvastatin-induced compartmentalisation of doxorubicin sharpens up nuclear topoisomerase II inhibition in human rhabdomyosarcoma cells. Naunyn Schmiedebergs Arch Pharmacol 386: 605-617, 2013.

5. Yu YH, Kuo HP, Hsieh HH, et al: Ganoderma tsugae induces $\mathrm{S}$ phase arrest and apoptosis in doxorubicin-resistant lung adenocarcinoma H23/0.3 cells via modulation of the PI3K/Akt signaling pathway. Evid Based Complement Alternat Med 2012: 371286, 2012.

6. NCCN: Soft Tissue Sarcoma. NCCN Guidelines. Version 1. 2012.

7. Longhi A, Ferrari S, Tamburini A, et al: Late effects of chemotherapy and radiotherapy in osteosarcoma and Ewing sarcoma patients: the Italian Sarcoma Group Experience (1983-2006). Cancer 118: 5050-5059, 2012. 
8. Huang YW, Wang LS, Chang HL, et al: Effects of serum on (-)-gossypol-suppressed growth in human prostate cancer cells. Anticancer Res 26: 3613-3620, 2006.

9. Lian J, NiZ, DaiX, etal: Sorafenib sensitizes (-)-gossypol-induced growth suppression in androgen-independent prostate cancer cells via Mcl-1 inhibition and Bak activation. Mol Cancer Ther 11: 416-426, 2012.

10. Pang $\mathrm{X}, \mathrm{Wu} \mathrm{Y}, \mathrm{Wu} \mathrm{Y}$, et al: (-)-Gossypol suppresses the growth of human prostate cancer xenografts via modulating VEGF signaling-mediated angiogenesis. Mol Cancer Ther 10: 795-805, 2011.

11. Enyedy IJ, Ling Y, Nacro Y, et al: Discovery of small-molecule inhibitors of Bcl-2 through structure-based computer screening. J Med Chem 44: 4313-4324, 2001.

12. Oliver CL, Miranda MB, Shangary S, et al: (-)-Gossypol acts directly on the mitochondria to overcome $\mathrm{Bcl}-2$ - and $\mathrm{Bcl}-\mathrm{X}(\mathrm{L})$-mediated apoptosis resistance. Mol Cancer Ther 4: 23-31, 2005

13. Blackstaffe L, Shelley MD and Fish RG: Cytotoxicity of gossypol enantiomers and its quinone metabolite gossypolone in melanoma cell lines. Melanoma Res 7: 364-372, 1997.

14. Qui J, Levin LR, Buck J and Reidenberg MM: Different pathways of cell killing by gossypol enantiomers. Exp Biol Med (Maywood) 227: 398-401, 2002.

15. Wolter KG, Wang SJ, Henson BS, et al: (-)-gossypol inhibits growth and promotes apoptosis of human head and neck squamous cell carcinoma in vivo. Neoplasia 8: 163-172, 2006.

16. Reed JC: $\mathrm{Bcl}-2$ and the regulation of programmed cell death J Cell Biol 124: 1-6, 1994.

17. Porter AG and Jänicke RU: Emerging roles of caspase-3 in apoptosis. Cell Death Differ 6: 99-104, 1999.

18. Mego M: Telomerase inhibitors in anticancer therapy: gossypo as a potential telomerase inhibitor. Bratisl Lek Listy 103: 378-381, 2002.

19. Balci A, Sahin FI and Ekmekci A: Gossypol induced apoptosis in the human promyelocytic leukemia cell line HL 60. Tohoku J Exp Med 189: 51-57, 1999.

20. Tamir S, Zuris JA, Agranat L, et al: Nutrient-deprivation autophagy factor-1 (NAF-1): biochemical properties of a novel cellular target for anti-diabetic drugs. PLoS One 8: e61202, 2013.

21. Zhang M, Liu H, Guo R, et al: Molecular mechanism of gossypol-induced cell growth inhibition and cell death of HT-29 human colon carcinoma cells. Biochem Pharmacol 66: 93-103, 2003.
22. Ergun MA, Konac E, Erbas D and Ekmekci A: Apoptosis and nitric oxide release induced by thalidomide, gossypol and dexamethasone in cultured human chronic myelogenous leukemic K-562 cells. Cell Biol Int 28: 237-242, 2004.

23. Kvansakul M and Hinds MG: Structural biology of the Bcl-2 family and its mimicry by viral proteins. Cell Death Dis 4: e909, 2013.

24. Czabotar PE, Westphal D, Dewson G, et al: Bax crystal structures reveal how $\mathrm{BH} 3$ domains activate $\mathrm{Bax}$ and nucleate its oligomerization to induce apoptosis. Cell 152: 519-531, 2013.

25. Chang JS, Hsu YL, Kuo PL, Chiang LC and Lin CC: Upregulation of Fas/Fas ligand-mediated apoptosis by gossypol in an immortalized human alveolar lung cancer cell line. Clin Exp Pharmacol Physiol 31: 716-722, 2004

26. Yoon $\mathrm{O}$ and Roh J: Downregulation of KLF4 and the Bcl-2/Bax ratio in advanced epithelial ovarian cancer. Oncol Lett 4: 1033-1036, 2012

27. Mohammad RM, Wang S, Aboukameel A, Chen B, Wu X, Chen $J$ and Al-Katib A: Preclinical studies of a nonpeptidic small-molecule inhibitor of Bcl-2 and Bcl-X(L) [(-)-gossypol] against diffuse large cell lymphoma. Mol Cancer Ther 4: 13-21, 2005.

28. Maurya SK, Tewari M, Sharma B and Shukla HS: Expression of procaspase 3 and activated caspase 3 and its relevance in hormone-responsive gallbladder carcinoma chemotherapy. Korean J Intern Med 28: 573-578, 2013.

29. Kasten-Pisula U, Windhorst S, Dahm-Daphi J, Mayr G and Dikomey E: Radiosensitization of tumour cell lines by the polyphenol Gossypol results from depressed double-strand break repair and not from enhanced apoptosis. Radiother Oncol 83: 296-303, 2007.

30. Bushunow P, Reidenberg MM, Wasenko J, et al: Gossypol treatment of recurrent adult malignant gliomas. J Neurooncol 43: 79-86, 1999.

31. Nielsen OS, Judson I, van Hoesel Q, et al: Effect of high-dose ifosfamide in advanced soft tissue sarcomas. A multicentre phase II study of the EORTC Soft Tissue and Bone Sarcoma Group. Eur J Cancer 36: 61-67, 2000.

32. Garcia-Carbonero R, Supko JG, Manola J, et al: Phase II and pharmacokinetic study of ecteinascidin 743 in patients with progressive sarcomas of soft tissues refractory to chemotherapy. J Clin Oncol 22: 1480-1490, 2004.

33. Kapoor S: Attenuating effect of gossypol on tumor growth in systemic malignancies. Cell Biochem Biophys 67: 1551-1552, 2013. 